\title{
Hernia Societies-A Blessing or a Curse? Who Is Running Them? Ethical Surgeons or the Industry
}

\author{
Robert Bendavid \\ Shouldice Hospital, Thornhill, Ontario, Canada \\ Email: rbendavid@sympatico.ca \\ Received 15 April 2014; revised 14 May 2014; accepted 13 June 2014 \\ Copyright (C) 2014 by author and Scientific Research Publishing Inc. \\ This work is licensed under the Creative Commons Attribution International License (CC BY). \\ http://creativecommons.org/licenses/by/4.0/ \\ c) (7) Open Access
}

\begin{abstract}
The intended purpose of hernia societies is being lost. Originally, they were meant to be a venue for the dissemination of basic science, knowledge and sharing of acquired research, experiences by surgeons with the ultimate aim of improving a patient's lot. Instead, they have become venues and brokerage houses where the plastics industry may advertise and sell products which have barely been tested or about which the truth was never entirely revealed. An FDA approval, sadly, is not assurance that all is well. We are discovering these facts through the courts and the lay press. We, as surgeons, are not told the whole truth to impart to patients who expect nothing less! Have any of us been complicit, knowingly or not?
\end{abstract}

\section{Keywords}

Hernia, Mesh, Plastics Industry, Gadgets, Ethics, Polypropylene

The last meeting of the AHS (Americas Hernia Society) which took place on March 12-15, 2014 in Las Vegas (Nevada) was ominous and premonitory if not prophetic! Never before have I seen so many congregations furtively looking about, some speaking sotto voce while others did so... unbridled, but all passionately. Leaders of four South American Hernia Societies vowed never to return. Six former AHS presidents and many former board members, some annoyed, others angry, one frothing at the mouth but all disappointed, wondering what is going on and what the future will be like. The South Americans were speaking of forming a Pan-American Hernia Society which would listen to delegations from member countries, sister-societies, others of forming an International Hernia Society where participating members would have equal say in planning, programming, choice of speakers, topics and perhaps meetings outside the US if the "s" in Americas Hernia Society name is to be sincere, welcoming and imply collaboration and respect for one's neighbours. Mostly, they wanted democracy in the AHS, not nepotism or Borgia-like conspiracy and intrigue. 
The thread however was that something has happened to the AHS which is not in keeping with logic, reason, respect, propriety and even ethics! There was a talk of "intergenerational change" by the present administration, of getting rid of the "older surgeons"... one in particular, whose contribution to the birth and thrust of the AHS was no less than stellar and whose intelligence and wit I would wish to have if I reach his privileged age!

What seemed to stick in everyone's craw was the fact that a very recent past president was overheard stating, at a meeting of the Asian-Pacific Hernia Society that he controlled the AHS and will do so for many years to come through his former associates and residents whom he has appointed to the Board, in line for future presidencies and who will take directions from him! The same president who, before his parting address, wallowed in the praises, kudos, tribute, paeans from a fawning underling who, in his panegyric thought that Nyhus and Stoppa barely rated a mention in comparison! Certainly in their cited academic contributions! Bravado, swagger... definitely and plenty of it. Bravura, brilliance, elegant modesty... none. The narrator of that anecdote is a former president himself! As someone else proffered... not even false modesty! And so it came to be that the congregants seemed at times to be holding a session on the floor of the New York Stock Exchange! Will it be an ironic crash? A simple rebellion against autocracy, oligarchy? Times are changing!

Many described the meeting as the display of one research group which has formed a coterie intent on controlling this meeting and future ones. A criticism from a South American was that all the speakers at the "Lunch and Learn" were all "from the same group and hardly needed to change caps from their previous SAGES meeting”. They have also been seen at the meeting on Abdominal Wall Repair in Washington DC and will be there anew in June! They will be seen in Cleveland again, next month under the auspices of the Americas Hernia Society as if the AHS was a portable umbrella to be used only by a self appointed cabal. Surgeons from Canada to Chile saw nothing new but an approach from one particular group in the US on the re-application of older techniques by a new and superbly gifted generation of surgeons whose unchallenged domination of the field of hernia surgery will bring about a Renaissance of its own! Perhaps through force-feeding of newfangled yet to be proven gadgets whose cost are relatively astronomical. Personally, I missed the classics such as what could be new in anatomy and proven, safe, affordable techniques! Ironically, it is the ignorance of surgical anatomy which is at the source of that plague of long ago: the recurrence. The double irony is that the first ignorance led to the development of meshes and gadgets to eliminate recurrences. The triple irony is that neither meshes nor gadgets nor laparoscopy have lowered the stubborn recurrence rates [1]! The final irony is that now, as the pain problem takes on an ever more menacing aspect, many patients would be happy to trade their "pain” for a recurrence. And who will help do it? Surgeons do not like removing meshes because these prosthetic meshes are "inert", therefore they cannot be the problem!! They are too difficult to remove. If they were inserted laparoscopically, few want to take the risk! Some patients travel the world to have them removed at the cost of $\$ 30,000$ - 100,000 and they have the receipts to prove it. All that has been said so far may well be hearsay, gossip, rumors, canards, scuttlebutt, even dirt. A tattler and a flibbertigibbet were having a conversation about the meshes used in bladder and uterine suspensions in women (and occasionally in men) and the unreasonable size of the settlements awarded by the courts! Polypropylene eroding and becoming infected through vaginal walls, through urethras is a subject which elicits compassion from a judge towards husband and wife. Presumably the judge is a husband too! How different is an adjacent vaginal wall from an adjacent urinary bladder or femoral/iliac vein? Prominent too was the news that a certain company, presently sued in US court, has been "shredding evidence since 2007" which would have been incriminating to its operations [2].

If only I could have heard everything! I do have a hearing problem which does injustice to many conversations but also to appreciating the depth of the mesh issues. However, with good eyes, I was able to pore over the program and was truly struck, as others must have been I am sure, by a nagging question. Who has decided on the topics to be presented? Why? What is the theme? Who will benefit from the choice of speakers and their topics? Why such an emphasis on Abdominal Wall Reconstruction of massive incisional hernias, which, in the context of my hospital only accounts for $4 \%$ of 7500 cases a year? And we are neither slouches nor Johnniescome-lately in this discipline! We innovated the double mesh (Goretex-Marlex) in 1997 which had a memorable publication by being the very first article in the first issue of the Journal HERNIA [3]! Perhaps this type of surgery is the particular interest of “The Group”? A wheel can be re-invented! But will it spin beyond $360^{\circ}$ ?

Simultaneously a major problem in hernia repair which barely rated three minor presentations is pain in herniorrhaphy incisions and the various causes of inguinodynias. Hundreds of articles by now have told us that the incidence can vary from 5\% - 78\% [4]. An incidence which began to climb only since we began using polypropylene meshes! Will it become an epidemic, as the number of post-op years is beginning to accumulate? 
I was going to persist in understanding the aims of this AHS program of 2014. Then I saw the list of the "Faculty Disclosure". I rejoiced at finding my answer and thanked Albert Einstein for having said it for me..."It is a miracle that curiosity survives a formal education”!!

The Faculty Disclosure is one of the outstanding successes in Ethics. As in everything else, it is not always scrupulously respected, as I noted by scrutinizing the Faculty Disclosure list [5] which is formally handed to every participant at congresses and which speakers must announce at the beginning of their presentations. A summary of the disclosures is in order. There were 78 speakers according to that list. Only 36 of them had "Nothing to Disclose"!!! Of these, I personally knew 7 who should have listed at least one conflict of interest. One of them, at least two conflicts of interest! There were 42 speakers (59\%) who declared a conflict of interest. Of these 42 speakers, 23 acted as consultants to a total of 54 companies ( 1 company at least or 8 companies at most). Of these 42 speakers, 22 received grants from 44 companies ( 1 at least and four at most). Of these 42 speakers, 21 were listed on the "Speaker Bureau" of 47 companies ( 1 at least and 8 at most). There were two speakers who were fully employed by two major manufacturing companies. One speaker was on the board of the most major of companies!

One speaker turned out to be the most ingenious talent, with real brio and chutzpah... he was listed as having "grant funding" from 3 companies, a "provider of CME reviewer", "grant/research" from a major manufacturer, "equipment received from 4 companies", a "consultant for general and plastic surgery devices and other panels of the medical devices advisory committee of the FDA's center for devices and radiological health", "medicolegal consulting for various law firms and entities", "consultant for biomedical technology companies including 4 medical manufacturing companies" and finally "business and venture capital groups: 3 major such groups are listed".

In a simple arithmetic progression, 66[23 + $22+21]$ surgeons vaunted the supposed merits of $145[54+47+$ 44] companies! If each surgeon praised the offerings of each company to three colleagues, then you have 145[66 + (66 × 3)], 38,280 plugs (pun intended), not quite a geometric progression but close! And if one considers that each company represented at the meeting [I counted 17] performed their hard sell through their 3 - 5 men/ women sales forces (e.g. with this gadget, you don't need to know your anatomy or you must be a defender of $19^{\text {th }}$ century surgery) then you have an exponential progression of cosmic proportions for an attendance of 500 600 !

There was too, the AHSQC booth (quality collaborative), but as I found out on two communications (emails)... "Do not apply if you are not US Based"! But that is another story.

As if this were not enough, the AHS has a corporate alliance which sits on the board of the society. What capacity or function the alliance has should also be declared. They do pay their way into the society. They do sponsor many studies. They do finance special projects, allegedly at arm's length! An interesting and ambitious research project on incisional hernias led by the AHS excluded Canadian surgeons! How quickly we forget! Canadians created the AHS by wisely choosing the participants and bringing them together in 1996! The original board meeting was to be held at the Shouldice Hospital. The venue was changed at the last minute and the inaugural meeting held in Miami instead, where the weather was more welcoming than Toronto's in February 1997. It fell to Dr Arthur Gilbert, therefore, to incorporate the society in Florida and he was named the first president. That should not be confused with being "the founder" as he is often and mistakenly referred to! Dr Shouldice and I have that privilege. The story will find itself in a publication shortly with pictures and documents of the original proposals by a company which we objected to, since it wanted control the society for three years. Have we gone full circle, being swayed/governed by 17 newer companies?

It is sad in retrospect, that we, as naïve surgeons, have created the AHS only to become the promoters, the wholesalers, the middlemen, the distributors, and if truth be said, the peddlers of a 2 billion dollar industry which projects to be a 6 billion dollar behemoth within the next ten years. Our courts have been doing much more to extract the truth from these giant multinationals than their scientific researchers and collaborative faculties. George Wantz, used to say about some of our colleagues, that... "They have sold their soul to the devil”! Aesclapius and Hippocrates themselves may not be able to reverse the trend! Mercury and Hermes, the gods of financial gain and lucre have overwhelmed us. The ethics of our fathers are brightly burning and wafting from censers at the altars of St Bard, St Gore, holiest St Ehicon and other slightly less saintly apostles from the tar sands and oil fields of this infinitely venal world.

It won't be long till a confounded surgical world will clamor for a "green operation" of which the Shouldice Hospital has performed 360,000 over the last 70 years. With mesh being used in less than $2 \%$ of the cases, their 
recurrence rate is less than $1 \%$. They have often been accused of "knowing their anatomy" and of "knowing what they are doing”! Isn't that what a surgeon is expected to know? And while recurrences are not a major problem at the Shouldice Hospital, neither is the ubiquitous pain problem which mesh has spawned (from 5\% $78 \%$ in some series) everywhere else. But who will remember how to do a pure tissue repair? And incorporate mesh only when necessary? A mesh which has proven its safety and whose purpose should not be to gouge the patient or saddle him with severe pain, a serious handicap or intolerable debt.

I have been warned that I will lose many friends and colleagues for being sincere, open and obviously indignant! But I have often observed that a friend you lose, never was. Who can ever escape one's earliest teachings, especially from one’s father?! My father and finest teacher often reminded me... "Fais ce que dois, advienne que pourra" which translates to "Do what is right, let happen what might”! And so I did.

\section{References}

[1] Schumpelick, V. (2005) Hernia Repair 2005, San Diego, 9-12 February 2005, Abstract 46-I of AHS Meeting.

[2] Feeley, J. (2013) J \& J Lost or Destroyed Vaginal-Mesh Files, Lawyers Contend. Bloomberg News. http://www.bloomberg.com/news/2013-12-04/j-j-lost-or-destroyed-vaginal-mesh-files-lawyers-contend.html

[3] Bendavid, R. (1997) Composite Mesh (Polypropylene-e-PTFE) in the Intraperitoneal Position. A Report of 30 Cases. Hernia, 1, 5-8. http://dx.doi.org/10.1007/BF02426380

[4] Kehlet, H., Jensen, T.S. and Woolf, C.J. (2006) Persistent Postsurgical Pain: Risk Factors and Prevention. Lancet, 367, 1618-1625. http://dx.doi.org/10.1016/S0140-6736(06)68700-X

[5] AHS Programme (2014) Faculty Disclosure. Annual Conference, Las Vegas. 
Scientific Research Publishing (SCIRP) is one of the largest Open Access journal publishers. It is currently publishing more than 200 open access, online, peer-reviewed journals covering a wide range of academic disciplines. SCIRP serves the worldwide academic communities and contributes to the progress and application of science with its publication.

Other selected journals from SCIRP are listed as below. Submit your manuscript to us via either submit@scirp.org or Online Submission Portal.
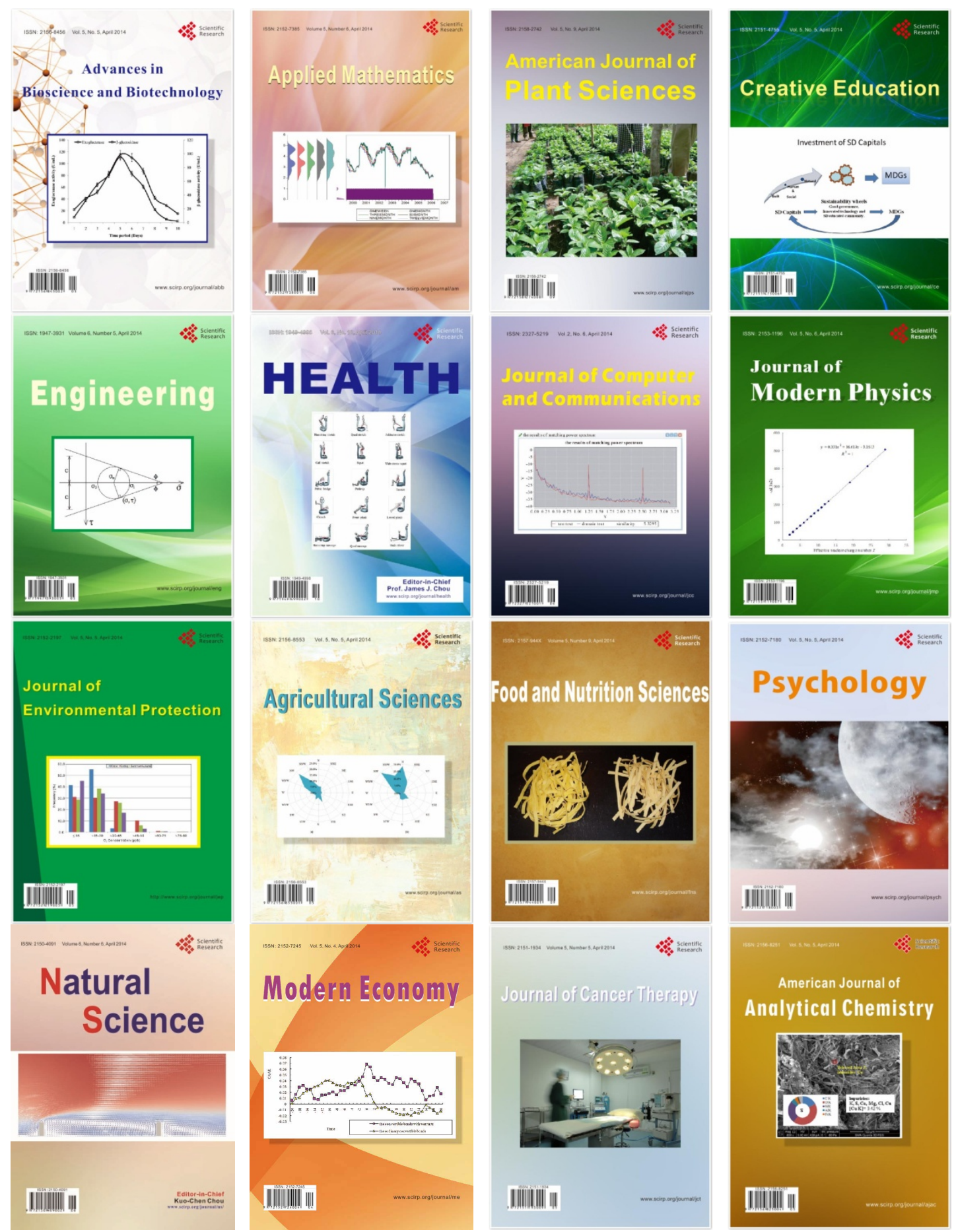